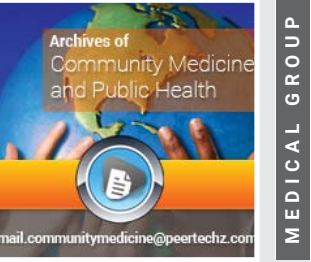

\section{Health quality of retired Royal New Zealand Navy personnel: A cross-sectional analysis}

\author{
Doug King ${ }^{1 *}$, Patria A Hume ${ }^{2}$, Trevor N Clark ${ }^{3}$ and Conor Gissane ${ }^{4}$ \\ ${ }^{1}$ Adjunct Research Fellow, School of Science and Technology, University of New England, Armidale, \\ NSW, Australia \\ ${ }^{2}$ Professor, National Institute of Stroke and Applied Neuroscience (NISAN), Faculty of Health and \\ Environmental Science, Auckland University of Technology, Auckland, New Zealand \\ ${ }^{3}$ International College of Management Sydney, Manly, New South Wales, Australia \\ ${ }^{4}$ Professor, School of Sport Health and Applied Science, St Mary's University, Twickenham, Middlesex, \\ United Kingdom
}

Received: 20 September, 2021

Accepted: 05 October, 2021

Published: 06 October, 2021

*Corresponding author: Doug King, Adjunct Research Fellow, School of Science and Technology, University of New England, Armidale, NSW, Australia,

E-mail: dking30@une.edu.au

ORCID: https://orcid.org/0000-0003-0135-0937

Keywords: Retired; RNZN; Navy; SF36-v2; Mental health; Physical pain

Copyright: (c) 2021 King D, et al. This is an openaccess article distributed under the terms of the Creative Commons Attribution License, which permits unrestricted use, distribution, and reproduction in any medium, provided the original author and source are credited.

https://www.peertechzpublications.com

\section{Check for updates}

\title{
Abstract
}

Purpose: To characterise the current health quality of retired Royal New Zealand Navy (RNZN) personnel.

Methods: A Cross-sectional analysis of self-reported survey data was conducted. A total of 300 retired RNZN personnel completed a Health-Related Quality of Life (HRQOL) survey on-line using the SF-36v2 to assess physical and mental health domains. The Physical Component Summary [PCS] combined Physical Function (PF), Role Physical (RP), Bodily Pain (BP) and General Health (GH) subscales. The Mental Component Summary [MCS] combined Vitality (VT), Social Functioning (SF), Role Emotional (RE) and Mental Health (MH) subscales. Analysis by age, gender, ethnicity, and rank were conducted for the subscale results. Comparisons of the RNZN cohort with the 1998 US National and New Zealand 2006-2007 health surveys were made.

Results: New Zealand Europeans (NZE) recorded a higher mean RP and PCS than New Zealand Māori (NZM) (RP: 66.9 vs. 54.9; $t_{(46)}=-2.2 ; p=0.0294 ; d=0.50 ;$ PCS: 68.9 vs. $\left.65.7 ; t_{(46)}=-2.3 ; p=0.0267 ; d=0.47\right)$. Senior Rates recorded a higher MH $\left(69.5\right.$ vs. $\left.66.2 ; t_{(19)}=-1.1 ; p=0.0568 ; d=0.35\right)$ but a lower PCS $\left(65.0\right.$ vs. $65.6 ; t_{(19)}=0.6 ; p=0.0681$ $d=0.07)$ and MCS (59.2 vs. $\left.59.4 ; t_{(19)}=-1.4 ; p=0.0865 ; d=0.46\right)$ than Officers. Compared with the New Zealand 2006-2007 health survey, the retired RNZN cohort had a lower $\operatorname{RP}(58.0$ vs. $85.7 ; d=1.14)$, BP (42.6 vs. $75.3 ; d=1.51)$, SF (59.8 vs. $88.4 ; d=1.85)$ and $\mathrm{MH}(68.5$ vs. $82.3 ; d=1.28)$.

Conclusion: The lower HRQOL subscales results (especially BP) for retired RNZN personnel compared to the general population and other service personnel indicates a need for more research to understand the potential reasons for these findings. The effects of the lifestyle and training requirements combined with the entry selection of healthy people into the navy may have impacted on the results reported in this survey.

\section{Introduction}

Serving in the Royal New Zealand Navy (RNZN) offers New Zealanders the chance to see the world, experience new places and to meet people from other countries engaged in similar roles and activities. The work undertaken in the navy differs from the work that non-RNZN personnel would experience in many aspects [1]. The work is primarily at sea, on a moving vessel, undertaken in both day and night environments and, at times, under a high work pressure $[1,2]$. In addition, navy personnel are exposed to noise, extremes in temperatures and weather conditions, radiation, gases, smoke and fumes from fires, guns and other weapons [3]. These risks placed upon navy personnel in the RNZN, similar to other navies worldwide, have the potential to negatively affect their health [4].

Defined as a multidimensional construct that encompasses one's appraisal of positive and negative aspects of their mental and physical health [5]. health-related quality of life (HRQOL) surveys provide a measure that is capable of providing more information beyond what can be obtained through medical records [6-8]. There are numerous studies [9-13], reporting the quality of life of clinical and non-clinical populations and more recently there is an increase in the number of studies reporting the quality of life for military personnel $[1,14-16]$. These studies

Citation: King D, Hume PA, Clark TN, Gissane C (2021) Health quality of retired Royal New Zealand Navy personnel: A cross-sectional analysis. Arch Community Med Public Health 7(3): 197-202. DOI: https://dx.doi.org/10.17352/2455-5479.000161 
have increased due to the broad range of health problems experienced from active duty service personnel who served in the 1990-1991 Gulf War [17,18] and now with the deployments of service personal world-wide to Iraq and Afghanistan [15]. Health hazards during deployment, and psychological distress during combat, may jeopardize health [19]. As a result of these deployments, musculoskeletal disorders, and injuries as well as mental health problems (i.e., depression, anxiety, substance abuse and post-traumatic stress disorder) are widely prevalent amongst military personnel [20-22]. Although there are studies reporting the HRQOL of some nation's service personnel, there has been, to-date, no published studies reporting the HRQOL of personnel serving or who have served in the RNZN. Therefore, the aim of this study was to assess the health-related quality of life of retired RNZN personnel.

\section{Methods}

Participants were sought through the lead author's online association with retired Royal New Zealand Navy (RNZN) Facebook contacts and organisations with the focus on retired RNZN personnel. Participants were requested to complete an online survey (www.surveygizmo.com) comprised of open ended and multi-choice questions over the period December 2017 to February 2018. The questionnaire covered aspects such as background information, injury/illness history, alcohol intake and the Quality of Life (SF-36v2) questionnaire. All information pertaining to the possible identification of the participants was removed through peer revision of the questionnaire. All questionnaires were individually reviewed in March 2018. Ethical consent was sought from the central region Health and Disability Ethics Committee (HDEC) but was reported to be not required.

\section{Short form questionnaire 36 version 2 (SF-36v2)}

Originally developed as a generic health-related quality of life survey (HRQOL) (SF-36) [23] the questionnaire was revised, and improved, to an 'international version' (i.e. SF36v2) enabling better cultural adaptation, diminished biases and ease of translation $[24,25]$. Consisting of 36 questions, the SF-36v2 is grouped into subscales describing either physical or mental domains. The physical domain (termed Physical Component Summary [PCS]) is assessed by combing the scores from the subscales reporting on Physical Function (PF) degree of health-related functional limitation; Role Physical (RP) - degree of physical health affects daily activities; Bodily Pain (BP) - degree of current bodily pain; and General Health (GH) - overall perception of physical health. The mental domain (termed Mental Component Summary [MCS]) is assessed by combining the scores from the subscales reporting on Vitality (VT) - general degree of perceived energy; Social Functioning (SF) - degree of health-related social limitation; Role Emotional (RE) - degree emotional health affects daily activities; and Mental Health (MH) - overall perception of mental health. A norm-based score, ranging from 0 to 100 , was calculated within each of the eight subdomains, as well as the PCS and MCS $[11,26]$. The normative scores of the SF-36v2 have a mean of 50 with a standard deviation of 10 , allowing for comparison to other populations [11]. A higher score in each of the domains and subscales indicates a better health status [11]. The SF-36v2 subscales have been reported [9] to have a Cronbach's alpha between $\alpha=0.67$ (SF) and $\alpha=0.95$ (RP). Validation scores for the PCS and MCS have been previously published [26].

\section{Categorical evaluation}

All completed questionnaires were downloaded onto a Microsoft Excel spreadsheet for verification. The data were separated into the following categories to enable further analysis: (1) Age groups (25-39, 40-49, 50-59, 60-69, 70-79 and 80+ yr.); (2) Gender (Male \& Female); (3) Ethnicity (New Zealand European; New Zealand Māori; Other European; Pacific Islander); and (4) Rank: Junior Rate (Able rate (AB), Leading Hand (LH)); Senior Rate (Petty Officer (PO), Chief Petty Officer (CPO), Warrant Officer (WO)); and Officer: (Lieutenant (Lt), Lt Commander (LtCdr), Captain (Capt.) to Commodore (Cdre)). Where there were a combination of ethnicities identified (i.e. New Zealand Māori and New Zealand European) New Zealand Māori was counted as the prime ethnicity. No completed questionnaires were excluded from analysis.

\section{Statistical analysis}

Sample size was calculated using the modified Cochran formula for small populations [27]. The target sample size calculated with 278. Data for the SF-36v2 questionnaire were extracted onto a separate spreadsheet and analysed with SPSS version 25.0 (IBM, New York, USA). After testing for normal distribution with the Shapiro-Wilk test $\left(W_{(300)}=0.067\right.$; $p=0.0022$ ), the mean and $95 \%$ confidence interval were identified. To compare between age groups, gender, ethnicity, and rank variables, $t$-tests were utilised to test for significant differences. Cohen's $d$ effect sizes were also computed to complement interpretation of results, with effect sizes being interpreted as negligible/very small $(d<0.20)$, small $(d=0.20$ to $0.49)$, medium $(d=0.50$ to 0.79$)$, or large $(d>0.80)[28,29]$. The level of significance was set at $p \leq 0.05$.

\section{Results}

Three hundred completed questionnaires were included for analysis.

\section{Age}

The average age of the respondents was $61.2 \pm 11.6$ yrs with a range of 25 to 90 yrs. (Table 1). Participants in the 50 to $59 \mathrm{yr}$. age group had a lower BP when compared with the 70 to 79 yr. $\left(t_{(55)}=-2.8 ; p=0.0068 ; d=0.51\right)$ and $80+$ yr. $\left(t_{(8)}=-\right.$ $2.5 ; p=0.0369 ; d=0.47)$ age groups. The 50 to $59 \mathrm{yr}$. group had a lower MCS when compared with the 60 to $69 \mathrm{yr} .\left(t_{(65)}=2.2\right.$; $p=0.0328 ; d=0.35)$ and 70 to 79 yr. $\left(t_{(55)}=3.8 ; p=0.0004 ; d=0.42\right)$ age groups.

\section{Gender}

Females had a lower GH but a higher RE when compared with males (GH: $t_{(21)}=2.7 ; p=0.0126 ; d=0.84 ; \mathrm{RE}: t_{(21)}=-2.3$; $p=0.0308 ; d=0.01)$. Although females recorded a lower PCS $\left(t_{(21)}=0.4 ; p=0.7042 ; d=0.06\right)$ and a higher MCS $\left(t_{(21)}=-1.7\right.$; $p=0.1083 ; d=0.28)$ than males these were not significant. 
Table 1: Age, total years' service, SF-36v2 Quality of Life health questionnaire scales and domains by total, male, female and age groups for retired Royal New Zealand Navy personnel reported by mean and standard deviation with range of age and service years and $95 \%$ confidence intervals for the SF-36v2 scales and domains.

\begin{tabular}{|c|c|c|c|c|c|c|c|c|c|c|}
\hline & Total & Male & Female & 25-39 yr. & $40-49$ yr. & $50-59$ yr. & 60-69 yr. & $70-79$ yr. & $80+y r$. \\
\hline & & $\begin{array}{c}\text { Mean } \pm S D \\
\text { [Range] }\end{array}$ & $\begin{array}{c}\text { Mean } \pm S D \\
\text { [Range] }\end{array}$ & $\begin{array}{c}\text { Mean } \pm S D \\
\text { [Range] }\end{array}$ & $\begin{array}{c}\text { Mean } \pm S D \\
\text { [Range] }\end{array}$ & $\begin{array}{c}\text { Mean } \pm S D \\
\text { [Range] }\end{array}$ & $\begin{array}{c}\text { Mean } \pm S D \\
\text { [Range] }\end{array}$ & Mean $\pm S D$ [Range] & Mean $\pm S D$ [Range] & $\begin{array}{c}\text { Mean } \pm S D \\
\text { [Range] }\end{array}$ \\
\hline \multicolumn{2}{|c|}{ Age (yr.) } & $\begin{array}{c}61.2 \pm 11.6 \\
{[25-90]}\end{array}$ & $\begin{array}{c}61.3 \pm 11.6[25- \\
90]\end{array}$ & $\begin{array}{c}60.5 \pm 11.5[31- \\
78]\end{array}$ & $35.5 \pm 4.4$ [25-39] & $46.1 \pm 3.0[40-49]$ & $55.9 \pm 2.4[51-59]$ & $64.5 \pm 2.8[60-69]$ & $73.4 \pm 2$. & $\begin{array}{c}84.0 \pm 3.2 \\
{[80-90]}\end{array}$ \\
\hline \multicolumn{2}{|c|}{$\begin{array}{l}\text { Service } \\
\text { (yr.) }\end{array}$} & $15.1 \pm 8.5[1-41]$ & $15.0 \pm 8.6[1-41]$ & $16.0 \pm 7.4[6-32]$ & $7.8 \pm 3.8$ [3-14] & $11.6 \pm 6.6[2-25]$ & $14.8 \pm 8.7[2-39]$ & $17.5 \pm 9.0[1-41]$ & $14.9 \pm 7.1[6-35]$ & $\begin{array}{c}19.4 \pm 11.3 \\
{[7-36]}\end{array}$ \\
\hline \multicolumn{2}{|c|}{ Ranks } & $A B$ to $C d r e$ & $A B$ to $C d r e$ & $A B$ to $\mathrm{LtCdr}$ & $\mathrm{AB}$ to $\mathrm{CPO}$ & $A B$ to $\mathrm{LtCdr}$ & $A B$ to $C d r e$ & $A B$ to $\mathrm{LtCdr}$ & $A B$ to $\mathrm{LtCdr}$ & $\mathrm{LH}$ to $\mathrm{LtCdr}$ \\
\hline \multicolumn{3}{|c|}{ SF-36v2 Scales } & & & & & & & & \\
\hline \multirow{5}{*}{ 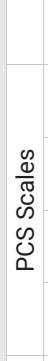 } & & Mean $(95 \% \mathrm{Cl})$ & Mean $(95 \% \mathrm{Cl})$ & Mean $(95 \% \mathrm{Cl})$ & Mean $(95 \% \mathrm{Cl})$ & Mean $(95 \% \mathrm{Cl})$ & Mean $(95 \% \mathrm{Cl})$ & Mean $(95 \% \mathrm{Cl})$ & Mean $(95 \% \mathrm{Cl})$ & $\begin{array}{c}\text { Mean }(95 \% \\
\mathrm{Cl})\end{array}$ \\
\hline & PF & $82.2(80.0-84.3)$ & $87.3(79.8-94.7)$ & 88.5 (82.7-94.3) & $91.5(82.4-100.0)^{\mathrm{h}}$ & $92.8(88.8-96.9)^{\mathrm{rgh}}$ & 86.8 (83.4-90.1) & $80.0(76.3-83.7)^{d}$ & $74.5(69.2-79.9)^{\mathrm{dh}}$ & $\begin{array}{c}67.8(56.0- \\
79.6)^{\mathrm{cdg}}\end{array}$ \\
\hline & RP & $58.0(54.9-61.1)$ & $60.7(49.6-71.8)$ & $61.6(50.3-72.9)$ & $65.0(51.5-78.5)$ & $63.0(52.5-73.5)$ & $63.1(57.5-68.7)^{g h}$ & $56.4(51.0-61.8)$ & $51.8(44.7-58.9)^{\mathrm{e}}$ & $\begin{array}{c}47.2(34.5- \\
60.0)^{\mathrm{e}}\end{array}$ \\
\hline & $\mathrm{BP}$ & $42.6(40.4-44.9)$ & $35.1(27.3-42.9)$ & $38.9(31.6-46.1)$ & $30.7(25.2-36.3)^{\mathrm{fh}}$ & $37.4(30.3-44.5)^{g}$ & $39.5(35.0-44.0)^{\mathrm{gh}}$ & $44.1(40.3-17.9)^{c}$ & $49.4(43.9-54.8)^{\mathrm{de}}$ & $\begin{array}{c}47.5(35.5- \\
59.4)^{c e}\end{array}$ \\
\hline & $\mathrm{GH}$ & $60.7(59.4-61.9)$ & $59.1(54.7-63.5)^{\mathrm{b}}$ & $53.3(49.2-57.3)^{\mathrm{a}}$ & $61.3(56.3-66.2)$ & $62.4(58.4-66.3)$ & $59.4(57.1-61.7)^{f}$ & $62.2(59.8-64.6)^{\mathrm{e}}$ & $59.6(56.1-63.2)$ & $\begin{array}{c}55.6(50.4- \\
60.8)\end{array}$ \\
\hline \multirow{6}{*}{$\begin{array}{l}\frac{0}{D} \\
\mathcal{D} \\
\mathcal{D} \\
\mathcal{U} \\
\Sigma\end{array}$} & VT & $55.1(54.1-56.0)$ & $53.5(50.6-56.3)$ & $52.4(49.6-55.1)$ & $53.8(51.4-56.1)$ & $52.1(49.5-54.8)^{f}$ & $53.6(51.9-55.4)^{f}$ & $56.7(55.2-58.2)^{\mathrm{de}}$ & $56.0(53.8-58.2)$ & $\begin{array}{c}56.4(49.5- \\
63.4)\end{array}$ \\
\hline & SF & $59.8(58.9-60.8)$ & $60.5(57.6-63.3)$ & $59.5(55.3-63.8)$ & $55.0(50.6-59.4)^{\text {gh }}$ & $58.5(56.1-60.9)^{\mathrm{h}}$ & $60.2(58.3-62.0)$ & $58.8(57.3-60.3)^{\mathrm{h}}$ & $62.0(60.0-64.0)^{\mathrm{c}}$ & $\begin{array}{l}66.7(59.0- \\
74.4)^{\mathrm{cdf}}\end{array}$ \\
\hline & $\mathrm{RE}$ & $61.9(59.5-64.4)$ & $53.6(46.8-60.4)^{b}$ & $61.8(52.5-71.2)^{a}$ & $59.6(48.7-70.5)$ & $61.2(52.8-69.7)$ & 60.7 (55.7-65.7) & $63.4(59.2-67.7)$ & $62.7(57.7-67.7)$ & $\begin{array}{c}58.5(40.6- \\
76.4)\end{array}$ \\
\hline & $\mathrm{MH}$ & $68.5(67.6-69.5)$ & $66.0(62.3-69.7)$ & 69.1 (65.5-72.7) & $68.5(64.0-73.0)^{\mathrm{h}}$ & $68.6(65.0-72.1)$ & $67.2(65.5-68.9)$ & $68.6(66.9-70.4)^{\mathrm{h}}$ & $69.2(67.2-71.2)$ & $\begin{array}{c}72.9(70.3- \\
75.5)^{\mathrm{cf}}\end{array}$ \\
\hline & PCS & $65.2(64.3-66.2)$ & $66.2(62.6-66.8)$ & $65.6(62.2-69.1)$ & $68.7(64.3-73.2)^{\mathrm{h}}$ & $69.9(67.5-72.4)^{\mathrm{fgh}}$ & $67.3(65.7-68.8)^{\mathrm{fgh}}$ & $64.7(63.1-66.4)^{\operatorname{degh}}$ & $61.7(59.4-64.0)^{\text {defh }}$ & $\begin{array}{c}56.8(51.8- \\
61.9)^{\text {cdefg }}\end{array}$ \\
\hline & MCS & $58.6(58.0-59.3)$ & $55.6(53.1-58.0)$ & $58.1(55.6-60.7)$ & $57.1(53.4-60.8)$ & $57.4(54.4-60.5)$ & $57.5(56.2-58.7)^{\mathrm{fg}}$ & $59.3(58.2-60.5)^{\mathrm{eh}}$ & $59.6(58.3-60.9)^{\mathrm{e}}$ & $\begin{array}{c}61.3(57.3- \\
65.3)^{f}\end{array}$ \\
\hline
\end{tabular}

$\mathrm{AB}=$ Able rate; $\mathrm{LH}=$ Leading Hand; $\mathrm{CPO}=$ Chief Petty Officer; $\mathrm{LtCdr}=$ Lieutenant Commander; $\mathrm{Cdre}=$ Commodore; Scores are scaled from 0 to 100 with a mean of $50( \pm 10$ $\mathrm{SD})$. Higher scales represent better health and fewer role limitations. Lower scores represent poorer health and more role limitations. $\mathrm{Cl}=\mathrm{Confidence} \mathrm{Interval;} \mathrm{PF}=\mathrm{Physical}$ function; RP = Role Physical; BP = Bodily pain; GH = General Health; VT = Vitality; SF = Social Functioning; RE = Role Emotional; MH = Mental health; PCS = Physical Component Summary; MHS = Mental Health Summary; Significant difference $(p<0.05)$ than $(a)=$ males; $(b)=$ females; $(c)=25-39 \mathrm{yr} ;(d)=40-49 \mathrm{yr} ;(\mathrm{e})=50-59 \mathrm{yr} ;(\mathrm{f})=60-69 \mathrm{yr} ;(\mathrm{g})=70-79$ yr.; $(h)=80+y r$.

\section{Ethnicity}

New Zealand Europeans (NZE) recorded a higher mean RP and PCS than New Zealand Māori (NZM) (RP: $t_{(46)}=-2.2$; $p=0.0294 ; d=0.50 ;$ PCS: $t_{(46)}=-2.3 ; p=0.0267 ; d=0.47$ ) (Table 2$)$. People identified as Other Europeans (OEUR) recorded a higher $\mathrm{SF}$ than NZM $\left(t_{(8)}=-2.5 ; p=0.0353 ; d=0.48\right)$. Although NZE recorded a lower BP than NZM $\left(t_{(46)}=1.7 ; p=0.1000 ; d=0.32\right)$ and $\operatorname{OEUR}\left(t_{(8)}=-1.9 ; p=0.0910 ; d=0.50\right)$ this was not significant. As a result, NZE recorded a higher PCS and a higher MCS than NZM (PCS: $t_{(46)}=-2.3 ; p=0.0267 ; d=0.47 ; \operatorname{MCS}: t_{(46)}=-1.0 ; p=0.3318$; $d=0.22)$.

\section{Rank}

The average duration of time serving in the RNZN was $15.1 \pm 8.5$ yrs. with a range of 1 to 41 yrs. The sample was representative of all ranks ranging from the $A B$ to the officer rank of Cdre.

Junior Rates were younger than Senior Rates $\left(t_{(107)}=-4.0\right.$; $p=0.0001 ; d=0.59)$ and Officers $\left(t_{(19)}=-3.8 ; p=0.0013 ; d=0.52\right)$ and reported a shorter service time than Senior Rates $\left(t_{(107)}=-\right.$ 11.8; $p<0.0001 ; d=1.83)$ and Officers $\left(t_{(19)}=-7.2 ; p<0.0001\right.$; $d=1.96)$. Although Junior Rates had a higher mean BP $\left(t_{(19)}=0.3\right.$; $p=0.6187 ; d=0.16)$, lower RP $\left(t_{(19)}=-0.5 ; p=0.6351 ; d=0.16\right)$ and $\operatorname{RE}\left(t_{(19)}=-1.3 ; p=0.2132 ; d=0.40\right)$ than Officers, but these were not significant. Senior Rates recorded a higher $\mathrm{MH}\left(t_{(19)}=-1.1\right.$; $p=0.0568 ; d=0.35)$ but a lower PCS $\left(t_{(19)}=0.6 ; p=0.0681 d=0.07\right)$ and MCS $\left(t_{(19)}=-1.4 ; p=0.0865 ; d=0.46\right)$ than Officers and these were not significant.

\section{NZ Navy versus other cohorts}

A comparison with other published HRQOL studies and the participants in this study is shown in Figure 1. The US National survey undertaken in 1998 reported a higher PF (83.3 vs. 82.2; $d=0.49)$, GH (70.8 vs. $60.7 ; d=0.66)$ and VT (58.3 vs. 55.1; $d=0.21)$ than our retired RNZN cohort. Compared with the New Zealand 2006-2007 health survey, the retired RNZN cohort had a lower RP (58.0 vs. $85.7 ; d=1.14$ ), BP (42.6 vs. $75.3 ; d=1.51$ ), SF (59.8 vs. $88.4 ; d=1.85)$ and $\mathrm{MH}(68.5$ vs. $82.3 ; d=1.28)$.

\section{Discussion}

This is the first study to report on the HRQOL of retired RNZN personnel. Overall, it identified that when compared with other general population studies, the health of these retired RNZN personnel were lower than the general population. To identify the differences reported in this study with other studies [10-13], 
Table 2: The SF-36v2 Quality of Life health questionnaire scales and domains by rank and ethnicity for retired Royal New Zealand Navy personnel reported by mean and $95 \%$ confidence intervals.

\begin{tabular}{|c|c|c|c|c|c|c|c|c|}
\hline & & Junior Rates & Senior Rates & Officers & NZ European & NZ Māori & Other European & Pacific Islander \\
\hline & & Mean $\pm S D$ [Range] & Mean $\pm S D$ [Range] & Mean $\pm S D$ [Range] & Mean $₫ S D$ [Range] & Mean $\pm S D$ [Range] & Mean $\pm S D$ [Range] & Mean $\pm S D$ [Range] \\
\hline \multicolumn{2}{|c|}{ Age (yr.) } & $57.4 \pm 12.9[25-90]^{\mathrm{bc}}$ & $64.1 \pm 9.6[31-87]^{\mathrm{a}}$ & $63.5 \pm 10.3[46-84]^{a}$ & $62.6 \pm 11.4[25-90]^{\mathrm{efg}}$ & $55.2 \pm 10.9[31-81]^{\mathrm{df}}$ & $64.4 \pm 8.1[47-71]^{\mathrm{de}}$ & $54.0 \pm 14.5[36-69]^{0}$ \\
\hline \multicolumn{2}{|c|}{ Service (yr.) } & $8.5 \pm 4.0[1-23]^{\mathrm{bc}}$ & $19.4 \pm 7.4[4-41]^{\mathrm{a}}$ & $22.6 \pm 9.3[5-40]^{a}$ & $15.1 \pm 8.5[2-41]^{9}$ & $14.7 \pm 8.2[2-33]$ & $14.4 \pm 8.6[1-25]$ & $22.0 \pm 10.0[9-31]^{\mathrm{d}}$ \\
\hline \multicolumn{9}{|c|}{ SF-36v2 Scales } \\
\hline & & Mean $(95 \% \mathrm{Cl})$ & Mean $(95 \% \mathrm{Cl})$ & Mean $(95 \% \mathrm{Cl})$ & Mean $(95 \% \mathrm{Cl})$ & Mean $(95 \% \mathrm{Cl})$ & Mean $(95 \% \mathrm{Cl})$ & Mean $(95 \% \mathrm{Cl})$ \\
\hline \multirow{4}{*}{ 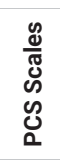 } & PF & $84.3(75.3-93.3)$ & $82.8(80.0-85.5)$ & $84.2(75.5-92.8)$ & $89.4(85.0-93.7)^{\mathrm{e}}$ & $84.5(80.0-89.1)^{d}$ & $83.3(73.5-93.2)$ & $81.1(35.5-96.7)$ \\
\hline & $\mathbf{R P}$ & $55.5(43.0-68.0)$ & $57.7(53.4-62.0)$ & $59.8(47.0-72.5)$ & $66.9(59.5-74.3)^{\mathrm{e}}$ & $54.9(48.1-61.7)^{d}$ & $57.8(35.9-79.7)$ & $53.3(36.5-93.2)$ \\
\hline & BP & $42.3(31.9-52.6)$ & $42.4(39.5-45.3)$ & $39.1(31.1-47.2)$ & $36.4(31.7-41.1)$ & $42.0(36.4-47.6)$ & $46.5(28.5-64.4)$ & $36.4(8.6-83.2)$ \\
\hline & GH & $61.4(55.2-67.6)$ & $59.3(57.5-61.1)$ & $59.8(54.5-65.1)$ & $60.3(57.7-63.0)$ & $62.2(59.1-65.4)$ & $62.7(56.1-69.2)$ & $61.3(38.4-84.3)$ \\
\hline \multirow{6}{*}{ 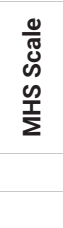 } & VT & $52.2(49.3-55.1)$ & $55.7(54.4-57.0)$ & $55.4(53.1-57.7)$ & $53.3(51.2-55.3)$ & $53.0(51.1-55.0)$ & $56.0(49.0-63.0)$ & $54.7(48.9-60.4)$ \\
\hline & SF & $58.5(54.7-62.3)$ & $60.5(59.2-61.7)$ & $60.5(56.9-64.1)$ & $58.3(56.1-60.5)$ & $59.4(57.3-61.4)^{f}$ & $62.2(58.8-65.6)^{\mathrm{e}}$ & $56.7(42.3-71.0)$ \\
\hline & RE & $58.7(49.5-67.9)$ & $61.6(58.2-65.0)$ & $67.3(56.4-78.2)$ & $61.8(55.2-68.5)$ & $59.4(53.4-65.4)$ & $53.3(30.6-76.1)$ & $53.4(22.5-89.3)$ \\
\hline & MH & $66.6(62.3-70.9)$ & $69.5(68.2-70.8)$ & $66.2(63.3-69.1)$ & $69.7(67.9-71.5)^{\mathrm{e}}$ & $66.9(64.7-69.1)^{\mathrm{dg}}$ & $68.4(61.7-75.2)$ & $76.0(66.1-85.9)^{\mathrm{e}}$ \\
\hline & PCS & $65.6(61.4-69.7)$ & $65.0(63.7-66.2)$ & $65.6(62.1-69.1)$ & $68.9(66.9-71.0)^{\mathrm{b}}$ & $65.7(63.7-67.7)^{d}$ & $66.7(61.4-72.0)$ & $63.2(36.3-90.1)$ \\
\hline & MCS & $56.4(53.3-59.5)$ & $59.2(58.3-60.1)$ & $59.4(56.9-61.9)$ & $58.2(56.5-59.9)$ & $56.9(55.1-58.7)$ & $57.6(51.5-63.8)$ & $59.5(40.7-78.4)$ \\
\hline
\end{tabular}

Scores are scaled from 0 to 100 with a mean of $50( \pm 10$ SD). Higher scales represent better health and fewer role limitations. Lower scores represent poorer health and more role limitations. $\mathrm{Cl}=$ Confidence Interval; $\mathrm{PF}=$ Physical function; $\mathrm{RP}=$ Role Physical; $\mathrm{BP}=$ Bodily pain; $\mathrm{GH}=$ General Health; $\mathrm{VT}=\mathrm{Vitality} ; \mathrm{SF}=\mathrm{Social}$ Functioning; $\mathrm{RE}=\mathrm{Role}$ Emotional; $\mathrm{MH}=$ Mental health; PCS $=$ Physical Component Summary; MHS = Mental Health Summary; Significant difference $(p<0.05)$ than $(a)=$ Junior Rates; $(b)=$ Senior Rates; $(\mathrm{c})$ = Officers; $(\mathrm{d})$ = NZ European; $(\mathrm{e})$ = NZ Māori; $(\mathrm{f})$ = European; $(\mathrm{g})$ = Pacific Islander;

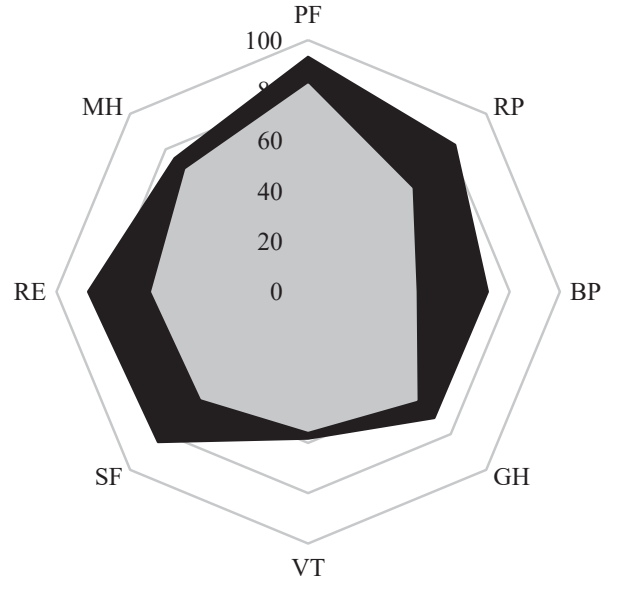

US National Survey $1998 \quad$ RNZN Retired

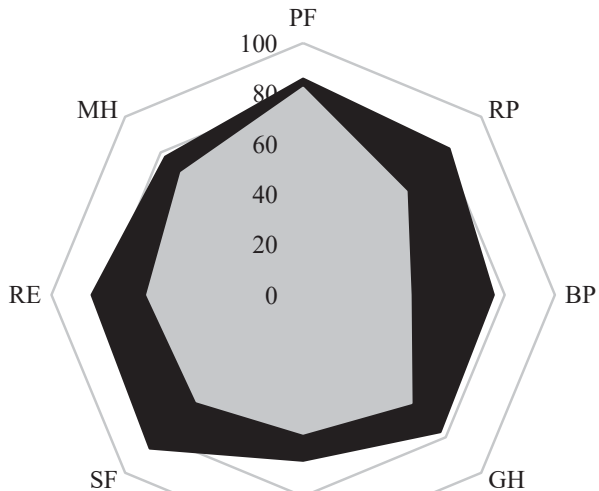

VT

-Canadian Multicentre Osteoporosis Study, $2000 \backsim$ RNZN Retired

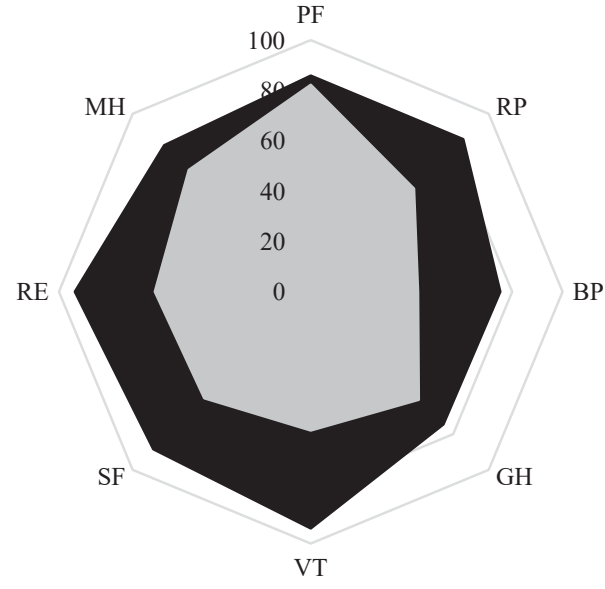

- New Zealand 2006-7 RNZN Retired

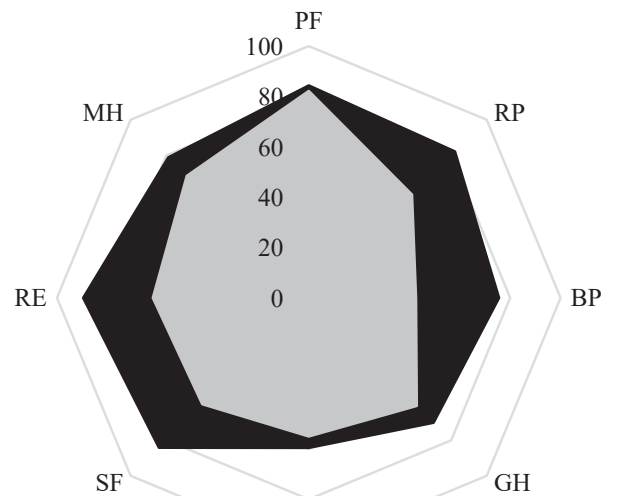

VT

- South Australia $2008 \quad$ RNZN Retired

Figure 1: Comparison of the scales of the total SF-36v2 results for retired Royal New Zealand Navy personnel with US National survey (1998) [11], New Zealand National Health survey (2006-7) [12], Canadian Multicentre Osteoporosis Study (2000) [13] and South Australian survey (2008) [10]. Scores are scaled from 0 to 100 with a mean of 50 ( \pm 10 SD). Higher scales represent better health and fewer role limitations. Lower scores represent poorer health and more role limitations. RNZN = Royal New Zealand Navy; PF = Physical function; RP = Role Physical; BP = Bodily pain; $\mathrm{GH}=$ General Health; VT = Vitality; SF = Social Functioning; RE = Role Emotional; MH = Mental health.

Citation: King D, Hume PA, Clark TN, Gissane C (2021) Health quality of retired Royal New Zealand Navy personnel: A cross-sectional analysis. Arch Community Med Public Health 7(3): 197-202. DOI: https://dx.doi.org/10.17352/2455-5479.000161 
a difference of five points in the scores is considered clinically and socially meaningful [13]. The mean scores for the subscales of the SF-36v2 were greater than five points in all areas, except for PF when compared with the New Zealand National Health survey [12]. Of concern was the finding that the retired RNZN participants in this study reported a mean BP almost half of that reported for the participants of the New Zealand National Health [12] the US National Health [11]. South Australian [10]. Iranian military [16], and Canadian [13], survey's.

When comparing male and female retired RNZN personnel, the respondents were of a similar age, rank and service duration. They had similar mean scores for the subscales and domains. A limitation to some [10-12] of these surveys is they did not report the PCS and MCS domains of the SF-36v2. When compared with the Canadian survey [13] the retired RNZN personal had a higher mean PCS (65.2 vs. 50.5) and MCS (58.6 vs. 51.7). This was unexpected considering that most subscales had a lower mean score. This was similar when comparing male and female retired RNZN personnel (Table 3) with Navy and Coast Guard personnel [14].

Male and female retired RNZN personnel reported a higher PF, PCS and MCS but the other subscales were lower than those reported for male and female New Zealanders aged 55 to 69 yrs [9]. Despite the low subscales reported, it was interesting to see that the overall PCS and MCS were higher. These differences may be related to the training that RNZN personnel have undertaken when serving, combined with the lifestyle a naval serviceperson undertakes when compared with non-RNZN personnel. This is a limitation to this study and future studies may consider this aspect when comparing service-personnel to non-service-personnel survey results.

The navy is selective in the enlistment of personnel with an entry medical examination that requires those selected to be generally healthy as well as undertaking selective assessments prior to employment [30]. The effects of the lifestyle and training requirements combined with the selection of healthy people into the navy may have impacted on the results reported in this survey. Further research is warranted to identify if these aspects influence the findings such as those reported here.

When compared by ethnicity, NZE recorded a higher PCS than NZM, OEUR and Pacific Islanders (PI) and this was similar

Table 3: Comparison of the SF-36v2 Quality of Life health questionnaire Physical and Mental Component Summary scores for retired RNZN and Millennium Cohort [14] (Navy and Coast Guard) study participants.

\begin{tabular}{|c|c|c|c|c|}
\hline & \multicolumn{2}{|c|}{ Retired RNZN personnel } & \multicolumn{2}{|c|}{$\begin{array}{l}\text { Millennium Cohort } \\
\text { (Navy and Coast Guard) personnel }\end{array}$} \\
\hline & Male & Female & Male & Female \\
\hline & Mean $(95 \% \mathrm{Cl})$ & Mean $(95 \% \mathrm{Cl})$ & Mean $(95 \% \mathrm{Cl})$ & Mean \\
\hline PCS & $66.2(62.6-66.8)^{\mathrm{b}}$ & $65.6(62.2-69.1)^{\mathrm{b}}$ & $53.8(53.7-54.0)^{a}$ & $53.2(52.9-53.4)^{\mathrm{a}}$ \\
\hline MCS & $55.6(53.1-58.0)$ & $58.1(55.6-60.7)^{\mathrm{b}}$ & $53.1(52.9-53.3)$ & $50.4(50.0-50.8)^{a}$ \\
\hline \multicolumn{5}{|c|}{$\begin{array}{l}\text { Scores are scaled from } 0 \text { to } 100 \text { with a mean of } 50 \text { ( } \pm 10 \text { SD). Higher scales represent } \\
\text { better health and fewer role limitations. Lower scores represent poorer health and } \\
\text { more role limitations. } \mathrm{CI}=\text { Confidence Interval; PCS = Physical Component Summary; } \\
\text { MCS = Mental Health Summary; Clinically significant ( } \geq 5 \text { points) than (a) = RNZN; (b) } \\
=\text { Millennium Cohort }\end{array}$} \\
\hline
\end{tabular}

to a previous study [9]. Interestingly all ethnicities recorded a higher PF than the previous study [9] but lower in the other subscales. New Zealand European's recorded a lower BP than the other ethnicities, however this conflicts with the study reporting on New Zealanders aged 55 to 69 yrs. The study by Stephens, et al. [9] reported that the BP recorded for NZE was 72.0, NZM was 66.6 and Pasifika was 57.8 . This finding is unique in that retired RNZN NZE recorded a similar BP to PI but lower than NZM. The reason for this finding is not clear and further research is warranted to explore this aspect.

There were no notable differences in the scores of the domains when compared by ranks for the current cohort. But when reviewed by subscales, Officers recorded a lower BP then JR and SR which was unexpected. When the results of the Officers subscales were compared with a previous study, it was identified that the RNZN personnel had lower subscores than those reported for Norwegian navy officers with variations ranging from $12(\mathrm{PF})$ to $50(\mathrm{BP})$ points. In a study on the Australian veterans from the 1991 Gulf War, it was reported [31] that lower rank was an occupational factor associated with both physical and mental ill-health and health-related quality of life in those service personnel involved in the 1991 Gulf war. Although most of the participants in this study would not have been involved in this activity, exposure to some form of traumatic event would have been likely and the effects of these exposures on long term psychological health tends to be underestimated in defence force personnel [31] Psychological ill-health can cause suffering and distress but also has adverse effects on the individual's cognitive processing of events, with major implications on their capacity to remain functioning in society [31]. This may be the case with the participants where they have undergone some form of traumatic event and may not have had this acknowledged or managed within their time in the RNZN. Further research is warranted to identify the types of traumatic events that have occurred and the effects of these on retired service-personnel.

\section{Conclusions}

This study indicates that the HRQOL of retired RNZN personnel is different in several areas when compared with studies reporting on the general population and other service personnel. The lower HRQOL subscales reported for the RNZN cohort indicates a need for further research to understand the potential reasons for these findings. Of concern is the low scores reported for BP of the retired RNZN personnel when compared with other studies. The effects of the lifestyle and training requirements combined with the entry selection of healthy people into the navy may have impacted on the results reported in this survey.

\section{Contributor statement}

According to the definition given by the International Committee of Medical Journal Editors (ICMJE), the authors listed above qualify for authorship based on making one or more of the substantial contributions to the intellectual content of:

Conception and design [DK; TC]; and/or,

Acquisition of data [DK]; and/or 
Analysis and interpretation of data [DK, PH, CG, TC]; and/

or

Participated in drafting of the manuscript [DK, PH, CG, TC]; and/or

Critical revision of the manuscript for important intellectual content [DK, PH, CG, TC].

\section{References}

1. Magerøy N, Riise T, Johnsen B, Moen B (2007) Health-related quality of life in the Royal Norwegian Navy: Does officer rank matter? Mil Med 172: 835-842. Link: https://bit.ly/3iA6IBn

2. de la Calle JFV, Rachou E, le Martelot MT, Ducot B, Multigner L, et al. (2001) Male infertility risk factors in a French military population. Hum Reprod 16: 481-486. Link: https://bit.ly/3a4TrXB

3. Goh VHH, Tong TYY, Lim CL, Low ECT, Lee LKH (2000) Circadian disturbances after night-shift work onboard a naval ship. Mil Med 165: 101-105. Link: https://bit.ly/2ZRXpAN

4. Boehmer TK, Boothe VL, Flanders WD, Barrett DH (2003) Health-related quality of life of U.S. military personnel: A population-based study. Mil Med 168: 941 947. Link: https://bit.ly/3Bb5MFm

5. The WHOQOL Group (1998) The World Health Organization quality of life assessment (WHOQOL): Development and general psychometric properties. Soc Sci Med 46: 1569-1585. Link: https://bit.ly/3BqohGd

6. Crosby RD, Kolotkin RL, Williams GR (2003) Defining clinically meaningful change in health-related quality of life. J Clin Epidemiol 56: 395-407. Link: https://bit.ly/2WF2ZFq

7. Moergeli H, Wittmann L, Schnyder U (2012) Quality of life after traumatic injury: A latent trajectory modeling approach. Psychother Psychosom 81: 305311. Link: https://bit.ly/3FgdQXZ

8. Schok ML, de Vries J (2005) Predicting overall quality of life and general health of veterans with and without health problems. Mil Psychol 17: 89-100. Link: https://bit.ly/3a4LdhR

9. Stephens C, Alpass F, Baars M, Towers A, Stevenson B (2010) SF-36v2 norms for New Zealands aged 55-69 years. NZ Med J 123: 47-57. Link: https://bit.ly/3uGw3ZE

10. Marin T, Taylor A, Gill T (2009) A population profile of the quality of life in South Australia - population norms for 2008 using the SF36 version 2. Adelaide: Population Research and Outcome Studies Unit. South Australian Department of Health.

11. Ware J, Kosinski M, Dewey J (2002) How to Score Version 2 of the SF-36 Health Survey (Standard and Acute Forms). 3rd ed. Lincoln (RI): QualityMetric. Link: https://bit.ly/3I8BU6T

12. Frieling M, Davis W, Chiang G (2013) The SF-36v2 and SF-12v2 health surveys in New Zealand: Norms, scoring coefficients and cross-country comparisons. Aust NZ J Public Health 37: 24-31. Link: https://bit.ly/3FgdZL1

13. Hopman WM, Towheed T, Anastassiades T, Tenenhouse A, Poliquin S, et al. (2000) Canadian normative data for the SF-36 health survey. Can Med Asso J 163: 265-271. Link: https://bit.ly/2YtHt7r

14. Smith TC, Zamorski M, Smith B, Riddle JR, A LeardMann C, et al. (2007) The physical and mental health of a large military cohort: baseline functional health status of the Millennium Cohort. BMC Public Health 7: 340-340. Link: https://bit.ly/3a4lOoE

15. Díaz Santana MV, Eber S, Barth S, Cypel Y, Dursa E, et al. (2017) Healthrelated quality of life among U.S. veterans of Operation Enduring Freedom and
Operation Iraqi Freedom-Results from a population-based study. Mil Med 182: e1885-e1891. Link: https://bit.ly/3a6RJ7T

16. Saffari M, Koenig HG, Pakpour AH, Sehlo MG (2015) Health related quality of life among military personnel: what socio-demographic factors are important? App Res Qual Life 10: 63-76. Link: https://bit.ly/2WJKekk

17. Kang HK, Mahan CM, Lee KY, Magee CA, Murphy FM (2000) Illnesses among united states veterans of the Gulf War: A population-based survey of 30,000 veterans. J Occup Environ Med 42: 491-501. Link: https://bit.ly/3l8eGxM

18. Dursa EK, Barth SK, Schneiderman Al, Bossarte RM (2016) Physical and mental health status of Gulf War and Gulf era veterans: Results from a large population-based epidemiological study. J Occup Environ Med 58: 41-46. Link: https://bit.ly/3uGwpPY

19. Buckman JEJ, Sundin J, Greene T, Fear NT, Dandeker C, et al. (2011) The impact of deployment length on the health and well-being of military personnel: A systematic review of the literature. Occup Environ Med 68: 69-76. Link: https://bit.ly/3FeZ7wm

20. Glad D, Skillgate E, Holm LW (2012) The occurrence and severity of musculoskeletal disorders in Swedish military personnel during peacekeeping operations in Afghanistan. Eur Spine J 21: 739-744. Link: https://bit.ly/2YkzmdA

21. Jacobson I, Horton J, LeardMann C, Ryan MA, Boyko EJ, et al. (2012) Posttraumatic stress disorder and depression among U.S. military health care professionals deployed in support of operations in Iraq and Afghanistan. J Trauma Stress 25: 616-623. Link: https://bit.ly/3uF8sbX

22. LeardMann CA, Powell TM, Smith TC, Bell MR, Smith B, et al. (2013) Risk factors associated with suicide in current and former us military personnel. JAMA 310: 496-506. Link: https://bit.ly/3DaGY0T

23. Ware J, Sherbourne C (1992) The MOS 36-Item Short-Form Health Survey (SF36): I. Conceptual Framework and Item Selection. Med Care 30: 473-483. Link: https://bit.ly/3DdgWKA

24. Turner-Bowker DM, Saris-Baglama RN, DeRosa MA (2013) Single-item electronic administration of the SF-36v2 Health Survey. Qual Life Res 22: 485490. Link: https://bit.ly/3BeVi7X

25. Atif M, Bashir A, Saleem Q, Hussain R, Scahill S, Babar ZUD (2016) Health related quality of life and depression among medical sales representatives in Pakistan. SpringerPlus 5: 1048. Link: https://bit.ly/3ix2aGD

26. Ware J, Kosoinski M, Bayliss M, McHorney C, Rogers W, et al. (1995) Comparison of methods for the scoring and statistical analysis of SF-36 health profile and summary measures: summary of results from the Medical Outcomes Study. Med Care 33: AS264-279. Link: https://bit.ly/3it92ET

27. Nanjundeswaraswamy D, Divakar S (2021) Determination of sample size and sampling methods in applied research. Proc Eng Sci 3: 25-32. Link: https://bit.ly/3iAilgG

28. Cohen J (1988) Statistical power analysis for the behavioural sciences. 2nd ed. New York, New York: Lawrence Erlbaum Associates. Link: https://bit.ly/3iy82iL

29. Zakzanis KK (2001) Statistics to tell the truth, the whole truth, and nothing but the truth: Formulae, illustrative numerical examples, and heuristic interpretation of effect size analyses for neuropsychological researchers. Arch Clin Neuropsychol 16: 653-667. Link: https://bit.ly/3mpspzJ

30. Kitchener S (2001) Ultraviolet radiation exposure and melanoma in Australian naval personnel. Aust Mil Med 10: 55-59. Link: https://bit.ly/2ZYMuW8

31. McKenzie D, Ikin J, MCFarlane A, Creamer M, Forbes AB, et al. (2004) Psychological health of Australian veterans of the 1991 Gulf war: An assessment using the SF-12, GHQ-12 and PCL-S. Psychol Med 34: 1419-1430. Link: https://bit.ly/3laphZf

Citation: King D, Hume PA, Clark TN, Gissane C (2021) Health quality of retired Royal New Zealand Navy personnel: A cross-sectional analysis. Arch Community Med Public Health 7(3): 197-202. DOI: https://dx.doi.org/10.17352/2455-5479.000161 